\title{
Structuralist Macroeconomics and the New Developmentalism
}

\author{
LUIZ CARLOS BRESSER-PEREIRA*
}

This paper first presents some basic ideas and models of a structuralist development macroeconomics that complements and actualizes the ideas of the structuralist development economics that was dominant between the 1940s and the 1960s. A system of three models focusing on the exchange rate (the tendency to the cyclical overvaluation of the exchange rate, a critique of growth with foreign savings, and new a model of the Dutch disease) shows that it is not just volatile but chronically overvalued, and for that reason it is not just a macroeconomic problem; as a long term disequilibrium, it is in the core of development economics. Second, it summarizes "new developmentalism" - a sum of growth policies based on these models and on the experience of fast-growing Asian countries.

Keywords: structuralism; development macroeconomics; exchange rate; developmentalism.

JEL Classification: E0; E19; O11; B22.

Neoclassical economics became dominant in universities in the second half of the 1970s. It was based on the general equilibrium model, rational expectations macroeconomics, and growth models. Although there is no direct link between this kind of thinking and the neoliberal policies and reforms proposed by the World Bank or by the Washington Consensus, neoclassical theory served as an allegedly scientific basis for them. Correspondingly, the theoretical alternative to neoclassical economics - the associated structuralist development economics that was dominant between the 1940s and the 1960s, including at the World Bank - lost influence and was no longer significantly renewed. As a result of this change in the ideological and theoretical hegemony and of the huge foreign debt crisis that in the 1980s debili-

\footnotetext{
* Emeritus professor of Getulio Vargas Foundation, e-mail: bresserpereira@gmail.com. Sumitted: 17/August/2011.
} 
tated the developing countries, particularly in Latin America, most of those countries submitted, one by one, to the policies of liberalization and deregulation prescribed by the neoliberal consensus. The exceptions were the fast-growing Asian countries that modernized their institutions and opened their economies to trade, but kept their capital accounts relatively closed and controlled their exchange rates.

It was in this setting that, from the beginning of the 2000s, there started to appear in Latin America, particularly in Brazil, a set of models and propositions that may be considered as a second moment of structuralist development economics - a structuralist development macroeconomics - which is no longer concerned with demonstrating the need to industrialize or to transfer labor to sectors with higher value-added per capita (these are taken as given) but focuses on macroeconomic prices, especially the interest rate and the exchange rate. At the same time a new national development strategy, rival both to the former national developmentalism and to the Washington Consensus, started to take shape and came to be called "new developmentalism". The new ideas reflected, on one hand, the failure of neoliberal reforms to promote development and to reduce inequality, and, on the other hand, the outdated nature of the old developmentalism given that many developing countries had reached a more advanced stage of development.

In this paper my purpose is to present the main theses of structuralist development macroeconomics and to compare them with the structuralist development economics that prevailed between the 1940s and the 1960s, and whose most important exponents were Paul Rosenstein-Rodan, Ragnar Nurkse, Gunnar Myrdal, Raul Prebisch, Celso Furtado, Hans Singer and Albert Hirschman. ${ }^{1}$

\section{STRUCTURALIST DEVELOPMENT ECONOMICS}

Since it was formulated in the 1940s and 1950s, structuralist development economics differed from the neoclassical vision in a number of respects. First, its method is different. Instead of formulating hypothetical-deductive growth models, it uses the historical-deductive method in order to understand economic systems and economic development. Therefore, it views economic development as a complex process of structural change that is historically translated as "industrialization", meaning the increase in productivity associated with the continuous transference of labor to sectors producing more technologically sophisticated goods and services, with higher value-added per worker, which require more educated and skilled labor and pay higher wages; that is also manifested in the continuous change

\footnotetext{
${ }^{1}$ The economic literature usually refers to the theory developed by these economists as "development economics" and, as a subgroup, calls "structuralist" the Latin American school that developed around the ideas of Raul Prebisch and Celso Furtado. However, since the expression "development economics" is too general, and since all said economists adopted a structural concept of development related to industrialization, I have decided to adopt the expression "structuralist development economics" to refer to this school of thought as a whole.
} 
in institutions and in values or ideologies; and whose primary cause is capital accumulation with the incorporation of technical progress.

Second, structuralist development economics maintained that the market is an excellent institution of economic coordination, but that economic development cannot rely exclusively on it. In the background there is always a nation and its corresponding state, determinedly seeking development through the formulation of a project or a national development strategy. It also maintains that underdevelopment is not "backwardness" but a relationship of dependence on, or subordination to, imperial or central powers that are indifferent, or even hostile, to the catching up of the new nation-states.

Third, it was concerned with the lack of lucrative investment opportunities because, contrary to what happens in developed countries, the first industrial enterprises to be installed do not take advantage of externalities flowing from the existence both of a group of enterprises oriented toward the same activity and of forward and backward linkages. For this reason, and also because the private sector would lack the ability to invest in economic infrastructure and in basic raw material industries, the state should promote forced savings and plan a "big push" - an extensive investment program.

Fourth, structuralist development economics presumed (erroneously, as we shall see) that developing countries including the middle income ones would not generate sufficient domestic savings to finance their development and, in addition, that they would be victims of a permanent shortage of hard currencies or dollars, and should therefore rely on foreign savings in order to grow.

Fifth, the structuralist theory denied that developing countries would enjoy permanent comparative advantage in the production of primary goods in which they should specialize, and rejected the condemnation of tariff protection made by conventional economics. Their critique was based on the infant industry thesis, on the thesis of the tendency to the decline in the terms of trade, and on the thesis of the high income-elasticity of the demand for manufactured goods versus the lowincome elasticity of the demand for primary goods.

Sixth, according to the classical model of Arthur Lewis, an unlimited supply of labor from an economy's primary and traditional sector makes industrialization possible with a small increase in wages, but, for this same reason, it creates a chronic shortage of domestic demand.

Seventh, the structuralist theory maintained that structural inflation would necessarily follow economic development, because the imperfection of markets, particularly the food production market, implied supply bottlenecks, which would be solved only through an increase in prices.

\section{THE NEW THESES AND TENDENCIES}

These ideas were developed in the early 1950s. Since then, a large number of countries have ceased to be merely agricultural in order to become pre-industrial 
or industrial and middle-income countries. At the same time, developed countries deregulated financial markets, commodities markets opened, and developing countries were now under strong pressure from the Washington Consensus to also open their financial markets. It is within this new framework that structuralist development macroeconomics has emerged in the 2000s. What does the new approach retain from the old one? A large portion of it. However, since the middle income countries concerned have already developed a reasonable industrial infrastructure, there is no longer any need to continue arguing in favor of strong state intervention in the economy due either to the "big push", or to the "foreign constraint" argument, that is, the lack of foreign hard currency that developing countries would need to grow. There is also no need to continue invoking the infant industries argument in order to justify their protection. On the other hand, the supply of agricultural goods has turned for long elastic to changes in prices, so that we can no longer talk about structural inflation. For all these reasons, the state has ceased to play a producer role and has become a promoter of investment and growth. As for the foreign constraint or developing countries' "need" for foreign savings in order to grow, the problem lies in superseding the old theses, not because those countries are in a new and more advanced phase of development, but because the old structuralist theory was mistaken about the role of foreign financing. In order to understand this problem, and, more broadly, structuralist development macroeconomics and the corresponding school of thought that is emerging - which might be called "Keynesian structuralist" - I now summarize its chief theses or propositions.

Structuralist development macroeconomics starts from the Keynesian assumption that the major bottlenecks to growth and to full employment lie on the demand side. The supply side is obviously essential — particularly education, technical progress, a good infrastructure - but these are problems on which most countries are already focusing their efforts. The chief problem of economic development one that is not clear to most government leaders, and which, once resolved, may lead a country to substantially increase its growth rate - lies in the lack of lucrative investment opportunities due to a lack of internal and external demand, and, consequently, in a relatively low rate of investment and saving.

According to this approach, two structural tendencies limit investment opportunities in developing countries: the tendency for wages to grow more slowly than productivity and the tendency to the cyclical overvaluation of the exchange rate. The first tendency, which has been emphasized and widely discussed by Celso Furtado and by other members of the structuralist school, limits the growth of the domestic market. Its basic cause is the unlimited labor supply existing in developing countries - a fact that holds down the real wages as long as the country does not reach the "Lewis moment", that is, the moment when this unlimited supply no longer exists. There is, of course, the argument that the developing countries should grow through concentrating income and, therefore, with wages growing more slowly than productivity "because in those countries the rich save more than the poor". But this idea is untenable: first, because it is not savings that determine investment, but it is investment that (duly internally financed) determines savings; 
second, because in those countries the rich have a high propensity to consume and their consumption tends to be directed toward imported goods; and third, because an increase in wages may reduce profit margins (the ratio of profit to sales), but if it causes an increase in the purchasing power of the domestic market that is proportionally greater than the decline in the profit margin, the profit rate may rise, and we will have a wage-led growth strategy. On the other hand, we must remember that, in the long run, on the assumption of neutral technical progress, an increase in wages of the same proportion as an increase in productivity encourages investment oriented to the domestic market, because the increase in wages is compatible with the maintenance of the profit rate at the level required to promote the investment provided that technical capital is neutral (the output-capital relation is constant). Wage-led growth, however, does not profit from the major advantage of the developing countries, namely, wages that are lower than those in the rich countries.

The second tendency - the tendency to the cyclic overvaluation of the exchange rate - places this macroeconomic price at the center of the theory of economic development. The exchange rate is usually not taken into account in this area of economic theory because it is presumed either that it floats gently around the current equilibrium, as in neoclassical theory, or that it floats in a volatile manner around this equilibrium, as in Keynesian theory. However, if the exchange rate instead tends to be overvalued, it is easy to understand why it will become a major obstacle to economic development. An overvalued exchange rate prevents modern and efficient enterprises in a developing country from having access to the international market. However, if the developing country is able to neutralize this tendency and the exchange rate remains at a competitive level, its efficient enterprises will have access to the entire external demand. In this case we have an export-led growth strategy supported by the country's ability to rely on a reasonable number of enterprises using the most modern technology, and by the government's ability to keep the exchange rate "competitive" or at the "industrial equilibrium" level which is defined as the exchange rate that favors enterprises using worldwide stateof-the-art technology.

In structuralist development macroeconomics we may distinguish five theses or propositions that are relatively new compared with the Keynesian and structuralist theses. ${ }^{2}$ The first thesis states that the exchange rate is the key variable of economic development. Neither conventional economics nor the structuralist theory viewed the exchange rate as part of development economics in so far as they presumed that exchange rate imbalances or "misalignments" would always be short term and would not show a tendency. In fact, the exchange rate tends to be cycli-

\footnotetext{
2 These theses and, more broadly, structuralist development macroeconomics and the new developmentalism are discussed in Globalization and Competition (Bresser-Pereira, 2010). This book makes use of several previous papers, among which it is worth mentioning Bresser-Pereira and Gala (2007) and Bresser-Pereira (2008).
} 
cally overvalued in developing countries, because of both the Dutch disease and excessive or unnecessary capital inflows, and, for that reason it is chronically or in the long germ overvalued. Thus, it is in the core of development economics.

First, structuralist development macroeconomics maintains that a competitive exchange rate is essential for economic development, because it works as a sort of light switch that "turns on" or "turns off" technological and administratively competent enterprises to global demand. A competitive exchange rate encourages export-oriented investments and correspondingly increases domestic savings. It is the rate located at the "industrial equilibrium" level, that is, corresponding to the exchange rate required for enterprises using worldwide state-of-the-art technology to be internationally competitive.

Structuralist development macroeconomics asserts that there is a tendency to the cyclical overvaluation of the exchange rate in developing countries. The exchange rate in developing countries does not float around the "current equilibrium" rate (which balances inter-temporally the country's current account); it is not a just volatile in the short term, as assumed by economic theory. This means that it is not controlled by the market, but by balance-of-payment crises (currency crises), by recurrent sudden stops and sharp devaluations. When there is no exchange-rate management policy to neutralize this tendency, the cycle starts with a financial crisis that abruptly and violently depreciates the exchange rate. The exchange rate, which was below the "current equilibrium" level when the cycle began, depreciates violently, and subsequently begins to appreciate, driven by two structural factors that become combined but that can be distinguished for better understanding. First, the Dutch disease pulls the exchange rate downwards ${ }^{3}$ or appreciates it until it reaches the current equilibrium level; however, it stops at this point, because the Dutch disease is compatible with the current account equilibrium. Second, and subsequently, capital inflows continue to bring about the appreciation of the exchange rate and produce the current account deficit, which is financed by those inflows. Foreign capital is attracted by the profit and interest rates, which tend to be higher in developing countries thanks to the lower wage levels and relative scarcity of capital. This structural attraction, however, would not be enough to cause high current-account deficits. These latter result from recurring erroneous policies, which continue to promote capital inflows and, therefore, to appreciate the exchange rate until that foreign creditors loose confidence and a new balanceof-payment crisis puts a stop to the process. These erroneous policies are: the growth with foreign savings policy, the exchange-rate anchor policy (usually incorporated into inflation-targeting policies), the policy of "financial deepening" or elimination of "financial repression", and, finally, exchange-rate populism. As long as the economic authorities pursue these policies, the country will go into a current account deficit, will become indebted, and will gradually lose creditors' confidence.

\footnotetext{
${ }^{3}$ An exchange rate is measured by dividing the domestic currency by the dollar or (as is usually done in developing countries) by a currency basket.
} 
At some point there occurs a sudden stop or a balance-of-payment crisis: the creditors cease to roll over the country's external debt, the country depletes its reserves and finally becomes delinquent and defaults on its obligations - and then the country's currency once again violently depreciates.

\section{DUTCH DISEASE}

The second thesis is on the Dutch disease or the natural resources curse. Instead of basing the argument in the assumption of existence of two sectors in the economy as Corden and Neary in their original model $(1982,1984)$, we assume two equilibrium exchange rates. The Dutch disease is an old problem, specific to monetary economies, but it received this name because it was identified in the Netherlands in the 1960s, when Dutch economists found that the discovery and export of natural gas were appreciating the exchange rate and threatening to destroy the country's entire manufacturing industry. It was only in the 1980s that the first theoretical model on the subject appeared. Even today, the literature on the subject is scarce and insufficient. The Dutch disease is a market failure that permanently overvalues the exchange rate, but it is consistent with the inter-temporal equilibrium of the current account. Even though in developing countries this failure constitutes a major obstacle to industrialization, neither development economics nor Latin American structuralist theory took it into account. Yet it was intuitively perceived, and was reflected in developmentalist economic policies. ${ }^{4}$ The import duties that structuralist theory advocated were not, after all, particularly protectionist, but were an effective way of neutralizing the Dutch disease on the import side, since the duties imply a devaluation of the currency for importers. On the other hand, those nations that subsidized the exports of industrial goods in the 1970s (such as Brazil and Mexico) were also neutralizing the Dutch disease on the export side, even if this was not clear to them. The duties on the one hand and the export subsidies on the other, from which the commodities giving rise to the Dutch disease were excluded, ended up as, in practice, the equivalent of a tax on these commodities. ${ }^{5}$

The Dutch disease, or "the natural resources curse", may be defined as the chronic or permanent overvaluation of a country's exchange rate caused by Ricardian rents arising from abundant and cheap resources, whose production is compatible with a current-equilibrium exchange rate that is clearly more appreciated than the industrial-equilibrium exchange rate. The "current equilibrium" exchange rate is here understood as the rate that balances inter-temporally the coun-

\footnotetext{
${ }^{4}$ Celso Furtado, for instance, in a 1957 report on the Venezuelan economy, practically defined the Dutch disease. This report was recently published by Centro Celso Furtado and Editora Contraponto (Furtado, 1956 [2008]).

${ }^{5}$ For instance, in Brazil in the 1970 s, the average import duty was $50 \%$ and the export subsidy on manufactured goods was also $50 \%$ on average. This way, the agricultural goods that did not have a subsidy paid a "disguised tax" of $33.3 \%$ on the exported price.
} 
try's exchange rate, and the "industrial equilibrium" exchange rate as the rate that economically favors enterprises in the tradable sector using worldwide state-of-theart technology. On this definition, the Dutch disease is a market failure that, by damaging the prospects of efficient and technologically sophisticated enterprises, prevents the structural change - the country's industrial diversification - that characterizes economic development. Several authors draw a distinction between Dutch disease and the curse of natural resources: whereas the former would be a market failure, the latter would result from corruption or from rent seeking made possible by the abundance of natural resources in countries where society likes cohesion and the state is weak and often captured by private interests. Although the problem of corruption exists in every country and is more serious in poor countries where there are Ricardian rents to be captured by corrupt individuals, we do not draw a distinction here between the two concepts, both because corruption is a criminal rather than an economic problem, and because the emphasis on corruption diverts attention from the economic phenomenon itself, namely, the permanent or chronic overvaluation of the exchange rate caused by the Dutch disease or by the curse of natural resources.

The countries affected by the Dutch disease may fall into three categories. The first category includes countries that have never industrialized (such as Venezuela). In the second category, countries that were able to industrialize for some time because, consciously or unconsciously, they neutralized the Dutch disease, but later adopted financial opening, lost control over their exchange rates, and either for that reason or because the prices of their exported commodities greatly increased engaged in a process of premature deindustrialization (such as Brazil). The final category includes countries that were industrialized and then discovered natural resources that gave rise to the Dutch disease (such as the Netherlands and Norway). Gabriel Palma (2005), using the terms defined by Robert Rowthorn (1994), points out that economic development follows a U-curve regarding industrialization: it is identified first with industrialization, and later with deindustrialization. From then on, Palma classifies middle-income countries into two groups: those that have no development alternative but to generate a surplus from the export of manufactured goods (such as the fast-growing Asian countries), and those that can generate this surplus from the export of commodities (such as Latin American countries); and he defines the Dutch disease as premature deindustrialization, as an "excess" of deindustrialization existing in countries rich in natural resources that are not able to prevent premature deindustrialization.

The severity of the Dutch disease is determined by the difference between the industrial-equilibrium exchange rate and the current-equilibrium exchange rate. The greater the difference, the more severe is the disease. The neutralization of the Dutch disease, in turn, is achieved when the policy of managing the exchange rate makes it competitive, taking it from the current-equilibrium level to the industrial-equilibrium level. A competitive exchange rate, therefore, is equivalent to the industrialequilibrium exchange rate. The neutralization of the Dutch disease is mainly effected through the imposition of a variable tax or levy on the commodity exports 
equal to the difference between the two rates in domestic currency. ${ }^{6}$ According to microeconomics teaching, a tax shifts upwards the supply curve of the good, because now the producers will only be willing to produce at a higher price. In this case, however, instead of the price of the commodity (which we presume constant; when it varies, the tax should vary accordingly), what matters is the exchange rate as compared to the amount offered. Once established an export tax, the supply curve of the commodity will shift upwards and to the left with regard to the exchange rate, that is, the producers will only be inclined to maintain production if the exchange rate depreciates in an amount corresponding to the tax. Therefore, if the tax is equal to the difference between the current equilibrium exchange rate and the industrial equilibrium exchange rate, the first one will shift towards the second and the Dutch disease will be neutralized, because, now, the new exchange rate will make for the country's manufacturing industry that uses internationally competitive technology. Even paying the tax, the commodity producers will continue to have the same profits; it is the country's population that "will pay" it, through the relative increase in the price of non-tradable goods resulting from the devaluation. The tax should be variable, so that the government might alter it according to the increase or decrease in the international price of each commodity.

Ideally, the government should use them to build international reserves and to create and invest in a sovereign fund, so that the inflows of hard currency stemming from commodity exports do not put pressure on the exchange rate as they are offset by capital outflows to the sovereign fund. Thus, government should not use the resources to finance current expenditures, except for a small amount $(a)$ to finance social policies that compensate for the decrease in wages, and $(b)$ to establish a second fund - a stabilization fund for agricultural commodities (if they rather than oil are responsible for the Dutch disease). This fund is necessary because Dutch disease resulting from agricultural goods is usually not serious; the prices of such goods are highly unstable, and sometimes their decline makes production unviable, even with a zero-rated tax and at the current-equilibrium exchange rate, and it becomes necessary to subsidize them.

If a Dutch disease country keeps the exchange rate around its industrial equilibrium, the country will have a current-account surplus and, provided that it invests the resources in the sovereign fund, a fiscal surplus. Yet, it is politically not easy to neutralize it because this implies depreciating the currency - which reduces wages in the short term (but increases them strongly in the medium term) and causes temporary but undesirable inflation.

How to measure the severity of the Dutch disease, $g$, or, in other words, what is the tax on the sales value of the good that takes it from the current equilibrium to the industrial equilibrium? It will be equal to the difference between the indus-

\footnotetext{
${ }^{6}$ Variable, because the tax should vary according to the variations of the international price of the commodity.
} 
trial-equilibrium exchange rate, $e_{\mathrm{i}}$, and the current-equilibrium rate, $e_{\mathrm{c}}$, divided by the export price of the commodity, $x$.

$$
g=\left(e_{\mathrm{i}}-e_{\mathrm{c}}\right) / x .
$$

A simple example helps to explain the problem. Let's assume two countries (A and $\mathrm{B}$ ) exporting two different commodities whose price in hard currency is equal to one monetary unit of hard currency. In country A the Dutch disease is mild, and therefore the current equilibrium exchange rate $\left(e_{\mathrm{c}}\right)$ is $\# 2.00$ and the industrial equilibrium exchange rate $\left(e_{\mathrm{i}}\right)$ is \#3.00 monetary units of the country per dollar. Yet in country B the disease is severe: the current-equilibrium exchange rate is the same, but the industrial-equilibrium exchange rate is \#40.00 monetary units of this country per dollar. In country A, therefore, the severity of the Dutch disease is relatively low, $33.3 \%$ with regard to the sale price of the good in local currency, whereas in country B the severity is much higher, $95 \%$.

$$
\begin{aligned}
& g_{\mathrm{A}}=(3-2) / 3=33,3 \% . \\
& g_{\mathrm{B}}=(40-2) / 40=95 \% .
\end{aligned}
$$

In order to neutralize the Dutch disease in country A, we will need a tax of only $33.3 \%$, whereas in country B a tax of $95 \%$ will be necessary. In a country producing agricultural goods, the severity of the Dutch disease will come closer to that of country A; in an oil-exporting country, it may reach the level of country B.

\section{CRITICISM OF THE POLICY OF GROWTH WITH FOREIGN FINANCING}

The fourth thesis of structuralist development macroeconomics is that the policy of growth with foreign savings that is usually combined with the policy of opening the country's capital account is unsound. We know that a growth with foreign savings policy, that is, growth with foreign indebtedness, implies in the medium term an increase in the country's financial vulnerability and, later, a balance-of-payment crisis. But before this it implies a usually high substitution of foreign for domestic savings as the exchange rate appreciates. Why? On the income side, because the appreciation of the currency artificially increases real wages, and, given a high marginal propensity to consume, increases consumption and reduces domestic savings. On the demand side, the exchange-rate appreciation reduces lucrative investment opportunities, export-oriented investments decline, and domestic savings decline. In both cases, foreign savings are not added to domestic savings but rather replace them.

Conventional economists often argue that it is "impossible" to manage the exchange rate in the long term, but experience tells us that this is not true: that the exchange rate may be managed by neutralizing the Dutch disease, by buying or selling foreign currency, and — note - by the policy of growth with foreign savings. In fact, when the economic authorities decide to grow with foreign savings, they are deciding to revalue the national currency, because the exchange rate that bal- 
ances inter-temporally a current-account deficit is more appreciated than the rate that is compatible with a zero or balanced current account. It is true that the existence of a current-account deficit should cause the market to depreciate the national currency, but it is reasonable to assume that the country will not have difficulty in getting foreign finance that checks the depreciation.

It could be argued that, in medium-development economies, in which incomes are highly concentrated or unequal, an increase in the workers' wages is not something negative, and will not necessarily reduce the profit rate in the event of a shortage of demand, as long as it encourages investment oriented to the domestic market. We must make it clear that wage increases resulting from a decrease in the remuneration of rentier capitalists (who live on interests, rents, and dividends) are always welcome in a national economy; after all, the main goal of economic development policies is to increase wages or standards of living. Yet an increase in wages at the cost of a decrease in the profit of enterprises to a level that is deemed to be considered, in Herbert Simon's terms, "unsatisfying" to them, will cause a decrease in the investment and growth rates. Thus, an artificial increase in wages caused by exchange-rate overvaluation rather than by productivity increase is not among the desirable ways of increasing the real wage.

How high will the rate of substitution of foreign for domestic savings be? This will depend on the elasticity of wages with regard to the exchange rate, and on the elasticity of consumption with regard to the variation in wages, which will be the higher for each household the higher is its marginal propensity to consume. In turn, the higher the sensitivity of exports and imports to the exchange-rate appreciation, the higher will be the disincentive for enterprises to invest. Profits and wages, therefore, apart from depending in the long run on the economy's level of productivity and on its pattern of income distribution, depend cyclically on the exchange rate, as do consumption, investment, and savings. The marginal propensity to consume, for its part, will depend on the difference between the interest rate and the profit rate, that is, on the investment opportunities existing in the economy. Under normal conditions, lucrative investment opportunities will be modest, and, consequently, the marginal propensity to save will be high. Under circumstances of accelerated growth and great profit opportunities, the capitalist class will invest greater part of its expected and earned income (increasing the propensity to invest), and, at the same time, there will also be an increase in the marginal propensity to consume, based on increases in working-class wages and particularly in middle-class salaries. Consequently, the rate of substitution of foreign for domestic savings will be lower than it would be should profit expectations be normal.

In formal terms, the rate of substitution of foreign for domestic savings may be measured in a simple way. Given the marginal propensity to consume and the elasticity of investments with regard to exports, the rate of substitution of foreign for domestic savings, $z$, is equal to 1 minus the variation in the rate of investment or total savings divided by the variation in the rate of foreign savings in the given period.

$$
\mathrm{z}=1-\left[(\mathrm{I} / \mathrm{Y})_{\mathrm{t}}-(\mathrm{I} / \mathrm{Y})_{(\mathrm{t}-1)}\right] /\left[(\mathrm{S} / \mathrm{Y})_{\mathrm{t}}-(\mathrm{S} / \mathrm{Y})_{(\mathrm{t}-1)}\right]
$$


If, for instance, the investment rate in a certain period varies from $20 \%$ to $21 \%$ of GDP, whereas in the same period the current-account deficit or foreign savings increased by $4 \%$ of GDP, the rate of substitution of foreign for domestic savings will have been $75 \%$; only $25 \%$ of the funds received from abroad were actually invested, and the remaining $75 \%$ were directed toward consumption.

Briefly, the tendency to the cyclical overvaluation of the exchange rate results, first, from the Dutch disease, which pulls the exchange rate up to the current equilibrium, and, subsequently, from the factors that encourage capital inflow. Among those factors, the growth with foreign savings policy is the most important - the one that poses the most dangers or risks for the country. Usually, this policy provokes a high rate of substitution of foreign for domestic savings, so that it is not investment that rises but consumption and foreign debt. We can, therefore, theoretically separate the causes of the exchange-rate overvaluation. Let us take the first example of the Dutch disease mentioned above, in which the exchange rate that balances inter-temporally the current account is \#2.00 monetary units of the country per dollar, and the industrial equilibrium exchange rate is \#3.00 monetary units per dollar. Let's assume, in addition, that the effective exchange rate is \#1.60 per dollar. In this case, the overvaluation caused by the Dutch disease is \#1.00, and the overvaluation caused by capital inflows due mainly to the policy of growth with indebtedness will be \#0.60 monetary units of the country per dollar.

\section{PUBLIC DEFICIT}

Besides rejecting current-account deficits, structuralist development macroeconomics, in this case opposed to vulgar Keynesianism, rejects chronic public deficits as a way of sustaining demand that would otherwise be chronically insufficient. According to this fifth thesis, chronic public deficits financially weaken the state - the nation's main instrument of collective action in the pursuit of economic development. It accepts them only as a countercyclical policy, necessary in times of recession. This idea was implicit in structuralist theory, and was never challenged by its major representatives, but it was the subject of a serious distortion, as long as, particularly in Latin America in the 1980s, vulgar Keynesianism criticized orthodox economists for defending fiscal responsibility and proposed chronic fiscal deficits as a way of fighting the shortage of demand. Keynes distinguished between the current budget and the capital budget, and argued that the former should be in balance. ${ }^{7}$ Recently, Robert Skidelsky, the remarkable biographer of Keynes, has returned to the subject by claiming that Keynes was not an apostle of fiscal deficits; on the contrary, "It may surprise readers to learn that Keynes thought that government budgets should normally be in surplus" (2009, p. xvi). Luiz Fernando de Paula (2008, p. 225), for his part, remarked that "Keynes advocated that the regular budget should be in balance the whole time or even in surplus, that it should be

\footnotetext{
${ }^{7}$ John Maynard Keynes, Collected Writings, vol. XXVII, chapter 5.
} 
transferred to the capital budget, whereas this latter might be temporarily unbalanced, although it should be in balance in the long run".

Structuralist development macroeconomics therefore adopts a similar attitude to public deficits as it does to current account deficits. Neither kind of deficit normally contributes to economic development.

\section{SUMMARY FIGURE}

Based on the five theses concerning the exchange rate, in the framework of the exchange-rate cycle, in Figure 1 we can see and compare three approaches to the exchange rate in developing countries. According to the conventional theory, the exchange rate floats in a controlled way around the current equilibrium exchange rate; according to the Keynesian theory, it floats in a volatile way, but still around the current equilibrium exchange rate. In contrast, the assumption of structuralist development macroeconomics is that there is a tendency to the cyclical overvaluation of the exchange rate. Whereas for the conventional and Keynesian theories it is still the market that controls the exchange rate, for structuralist development macroeconomics this role is performed by the balance-of-payment crisis; if the country does not manage its exchange rate, if it lets it float in a really free way, the country will experience successive balance-of-payment crises. In Figure 1, the ordinate represents the exchange rate in terms of domestic currency/reserve currency, so that the lower the position in the exchange rate curve, the more appreciated is the domestic currency.

Figure 1: Tendency to the overvaluation of the exchange rate

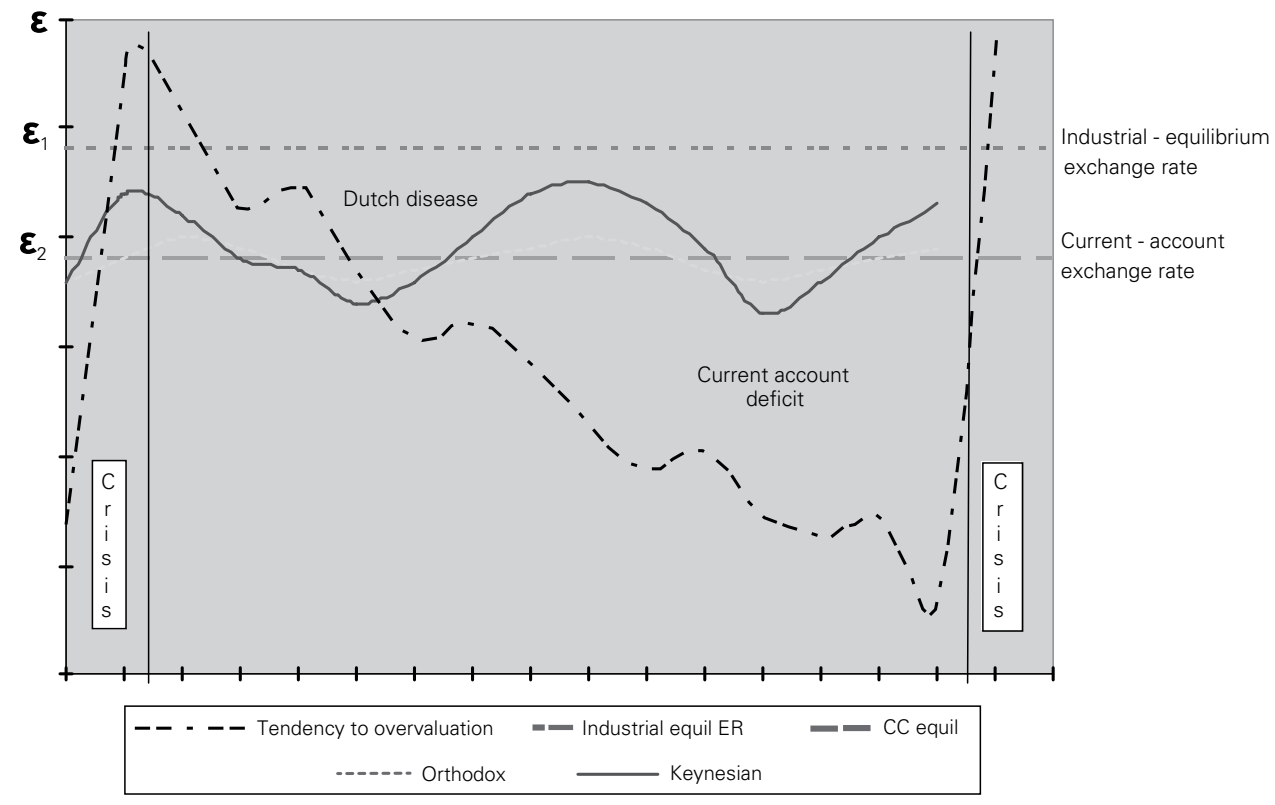


Given the assumption that the government does not manage the exchange rate, the tendency to the cyclical overvaluation of the exchange rate is manifested in a cycle that begins and ends with a currency crises or balance-of-payment crises. In Figure 1 we have three basic lines: two horizontal lines, one line for the currentequilibrium exchange rate and another one for the industrial-equilibrium exchange rate, and a third blue line that depicts the actual exchange rate. The story begins with a crisis or a sudden stop resulting from foreign creditors' loss of confidence. As we can see in the Figure 1, there is a sudden and violent devaluation that may take the exchange rate up to a more appreciated level than the industrial-equilibrium level. Subsequently, the forces that in developing countries appreciate the domestic currency begin to operate. First, on the assumption that the country has the Dutch disease, it is up to it to pull the exchange rate back to the current equilibrium level. If the disease is serious, this first movement already represents a major appreciation. But, since the Dutch disease is compatible with the inter-temporal equilibrium of the current account, the appreciation it causes stops there. Afterwards, the exchange rate continues to appreciate and enters the area of the current-account deficit due to excessive or unnecessary capital inflows. The structural cause of this second movement is the fact that market profits and interest are higher in developing countries. More significant, however, are the economic policy causes that encourage the capital inflows. Not only the growth with foreign savings policy, but also the use of the exchange rate by central bankers as an anchor to inflation, and "exchange-rate populism": the freezing of the nominal exchange rate and its real appreciation decided by politicians seeking reelection.

When the exchange rate crosses the line or the range of the current equilibrium, the country is in a deficit that must be financed. Besides, it has an external debt that continues to require financing. For a long period, however, the rollover and the increase in foreign debt are easily financed, because foreign creditors are happy with the nice interest and commissions they are receiving, or, in other words, because a credit bubble is in the making. Beyond a certain point, however, whether because the debt/export ratio is becoming too high (the basic explanation of exchange-rate crises in Latin America) or because the pace of growth of the currentaccount deficit is too high (which occurred in four Asian countries in 1997), the creditors eventually lose confidence and halt new loans, even those involving the mere rollover of debt. It is the crisis, and we once again have an abrupt devaluation of the domestic currency.

\section{OLD AND NEW DEVELOPMENTALISM}

Following this short presentation of structuralist development macroeconomics, we are in a position to set out, also in a condensed way, the new developmentalism - the national development strategy that forms an alternative to the Washington Consensus and that has been under discussion since the turn of the 
twenty-first century, having as its paradigm the fast-growing Asian countries. ${ }^{8}$ It is best presented by comparison with the old developmentalism and, later, with the conventional orthodoxy or the Washington Consensus. We are still referring to middle-income countries. Table 1, where the old developmentalism and the new developmentalism are compared, is self-explanatory. The changes in policy are not a criticism of national developmentalism; they just reflect the fact that this national development strategy is intended for poor countries, whereas the new developmentalism is intended for middle-income countries. The first difference - between import-substitution industrialization and export-led industrialization - well reflects this fact. The new developmentalism defends the export-led model and views the import-substitution model as outdated. In the export model, developing countries have the opportunity to exploit two major advantages: cheap labor and the possibility of buying or copying the available technology. On the other hand, if a country adopts this strategy, the economic authorities, who are making industrial policy in favor of their enterprises, can now base their decisions on an efficiency criterion: only enterprises efficient enough to export will benefit from the industrial policy.

Table 1: Old developmentalism and new developmentalism

\begin{tabular}{|c|c|}
\hline Old developmentalism & New developmentalism \\
\hline $\begin{array}{l}\text { 1. State-oriented industrialization, based on } \\
\text { import substitution. }\end{array}$ & $\begin{array}{l}\text { 1. Export-oriented industrialization, combined } \\
\text { with mass consumption on the domestic } \\
\text { market. }\end{array}$ \\
\hline $\begin{array}{l}\text { 2. State's key role in obtaining forced savings } \\
\text { and making investments. }\end{array}$ & $\begin{array}{l}\text { 2. It is the state's duty to create investment } \\
\text { opportunities and reduce economic } \\
\text { inequalities. }\end{array}$ \\
\hline 3. The industrial policy is a key issue. & $\begin{array}{l}\text { 3. The industrial policy is subsidiary but } \\
\text { strategic. }\end{array}$ \\
\hline $\begin{array}{l}\text { 4. Ambiguity about public and current account } \\
\text { deficits. }\end{array}$ & $\begin{array}{l}\text { 4. Rejection of both public and current } \\
\text { account deficits. If the country has the Dutch } \\
\text { disease, it should achieve a fiscal surplus and } \\
\text { a current-account surplus. }\end{array}$ \\
\hline 5. A certain complacency regarding inflation. & 5. No complacency regarding inflation. \\
\hline
\end{tabular}

Whereas in the national developmentalism the state's task was to complete the primitive accumulation of capital and promote the industrial revolution, in the new developmentalism the state's role decreases and the market's role increases. For the new developmentalism, the state still can and should promote

\footnotetext{
${ }^{8}$ In 2010 a group of development economists and macroeconomists debated and approved the Ten Theses on New Developmentalism. These are now available at www.tenthesesonnewdevelomentalism. org in several languages, with the name of their sponsors.
} 
forced savings and invest in certain strategic sectors, but now the domestic private sector has the resources and the entrepreneurial capacity to implement a good part of the necessary investments. On the same lines, for the old developmentalism industrial policy was central; in the new developmentalism it is still significant but strategic, and must be applied to specific sectors and to enterprises able to compete internationally.

The new developmentalism is not protectionist, but simply emphasizes the need for a competitive exchange rate, which it identifies as the industrial-equilibrium exchange rate. It assumes that medium-development countries have already progressed beyond the infant industry stage, but, besides the problem of excessive capital inflow, they face the problem of the Dutch disease, and therefore they need neutralize it. Such neutralization does not imply protectionism but rather exchangerate management, particularly, as we have seen, through the imposition of a variable export tax on the commodities giving rise to the Dutch disease that shifts the supply curve of the commodity upwards.

The fact that the strategy of the new developmentalism is not protectionist does not mean that countries should be inclined to indiscriminate trade opening. In the context of World Trade Organization and regional agreements, they should pragmatically negotiate openings with compensation. Above all, it does not mean that a country should renounce industrial policies. The scope for these policies was limited by the highly restrictive agreements of the Uruguay Round, but there is still some room for industrial policies, which, if they are strategically conceived and if take into account future comparative advantages, they will effectively promote economic growth.

\section{CONVENTIONAL ORTHODOXY AND NEW DEVELOPMENTALISM}

In order to compare the new developmentalism with conventional orthodoxy, we can differentiate development strategies from the strategies of macroeconomic stability, even though they are closely connected. Let's begin with the differences more directly related to economic development or to the medium term. Those differences are summarized in Table 2; we discuss them only briefly. Unlike with the comparison with the old developmentalism, the general problem here is not a change in the stage of development, but mistaken policies: conventional orthodoxy suggests a package of reforms and economic policies, many of them tainted with market fundamentalism, which are of interest not to developing countries but rather to their competitors in the framework of globalization - the rich countries. 
Table 2: Conventional orthodoxy and new developmentalism (growth)

\begin{tabular}{|l|l|}
\hline \multicolumn{1}{|c|}{ Conventional orthodoxy } & \multicolumn{1}{c|}{ New developmentalism } \\
\hline 1. There is no economic role for the nation. & $\begin{array}{l}\text { 1. The nation is the agent responsible for the } \\
\text { definition of a national development strategy. }\end{array}$ \\
\hline $\begin{array}{l}\text { 2. The fundamental institution for growth } \\
\text { is the guarantee of property rights and } \\
\text { contracts. }\end{array}$ & $\begin{array}{l}\text { 2. The key institution for growth is a national } \\
\text { development strategy. }\end{array}$ \\
\hline $\begin{array}{l}\text { 3. Reforms should reduce the size of the } \\
\text { state and deregulate markets. }\end{array}$ & $\begin{array}{l}\text { 3. Reforms should strengthen the state and } \\
\text { markets - and the latter should be well } \\
\text { regulated. }\end{array}$ \\
\hline $\begin{array}{l}\text { 4. The state should not implement an } \\
\text { industrial policy or a policy of redistribution. }\end{array}$ & $\begin{array}{l}\text { 4. Industrial policy should be limited and strategic, } \\
\text { and play a major role in income distribution. }\end{array}$ \\
\hline $\begin{array}{l}\text { 5. There are no structural tendencies to be } \\
\text { neutralized. }\end{array}$ & $\begin{array}{l}\text { 5. The tendency to currency overvaluation and } \\
\text { the tendency of wages to grow more slowly } \\
\text { than productivity should be neutralized. }\end{array}$ \\
\hline $\begin{array}{l}\text { 6. Growth should be financed largely by } \\
\text { foreign savings. }\end{array}$ & $\begin{array}{l}\text { 6. Growth should be based on domestic } \\
\text { savings. }\end{array}$ \\
\hline
\end{tabular}

The orthodoxy ignores the problem of the nation or else it presupposes that in times of globalization nation-states have lost significance. In contrast, the new developmentalism states that, in the context of widespread competition that characterizes globalization, the fundamental agent of economic development is the nation, because it is up to the nation - the social classes agreeing reasonably among themselves - to define a national development strategy or a strategy of international competition. Contrary to the claims of the new institutional economists and political scientists, the fundamental institution of development is not the guarantee of ownership and of agreements. This guarantee is necessary, but entrepreneurs accept the risk as long as they have an opportunity to make profits and grow. The institution or group of institutions that performs this role is the national development strategy.

Conventional orthodoxy is market fundamentalist, and believes that "in the beginning was the market", an entity that coordinates everything in an optimal way provided it is free; whereas the new developmentalism views the market as an efficient institution to coordinate economic systems, but is aware of its limitations. Good markets, efficient markets are regulated markets. Whereas conventional orthodoxy acknowledges market failures, but affirms that the failures of the state in trying to compensate for them are even worse, the new developmentalism rejects this pessimism about the power of collective action and wants a capable state strong, not at the cost of the markets, but in order to make markets strong also.

The new developmentalism rejects the chronic public deficits defended by vulgar Keynesianism, just as it opposes the current-account deficits defended by orthodox economists transformed into exchange-rate populists. It sees in both deficits ways of disorganizing and weakening the economic system: in the one instance we 
have fiscal irresponsibility, in the other exchange-rate irresponsibility. In order to ensure economic development with stability, the state's finances must be solvent. Well, public deficits and a huge public debt, as well as current-account deficits and a huge external debt, weaken the state, make it dependent on creditors - a state that should be strong or efficient because it is the nation's instrument of collective action par excellence.

In order to ensure the control of the exchange rate, the new developmentalism rejects the opening of the capital account, or financial globalization, but is favorable toward trade globalization - to a commercially open economy - because it assumes that middle-income countries no longer need to appeal to the infant-industry argument and the corresponding customs protection in order to compete internationally. But the new developmentalism is aware of the need to use international negotiations to obtain compensations, since world markets are far from being free. Both the new developmentalism and the conventional orthodoxy are favorable toward more flexible labor markets, but the new developmentalism, based originally on Scandinavian, but now increasingly European, experience of "flexsecurity", does not confuse flexibility with the absence of protection, and demands that the flexibility of occupational laws be compensated with an increase in state expenditure on unemployment benefits and with the training of workers made redundant for technological reasons. ${ }^{9}$

Table 3: Conventional orthodoxy and the new developmentalism (macro)

\begin{tabular}{|l|l|}
\hline \multicolumn{1}{|c|}{ Conventional orthodoxy } & \multicolumn{1}{|c|}{ New developmentalism } \\
\hline $\begin{array}{l}\text { 7. The Central Bank has a sole mandate: low } \\
\text { inflation. The rest of the administration should } \\
\text { pursue other goals. }\end{array}$ & $\begin{array}{l}\text { 7. The government and the Central Bank have } \\
\text { three mandates: low inflation, balanced } \\
\text { exchange rate and full employment. }\end{array}$ \\
\hline $\begin{array}{l}\text { 8. The fiscal standard should be defined in } \\
\text { terms of primary surplus. }\end{array}$ & $\begin{array}{l}\text { 8. The fiscal standard should be defined more } \\
\text { rigorously in terms of public deficit and public } \\
\text { savings. }\end{array}$ \\
\hline $\begin{array}{l}\text { 9. The exchange rate should be floating: no } \\
\text { target or policy for the exchange rate. }\end{array}$ & $\begin{array}{l}\text { 9. The exchange rate should be floating but } \\
\text { managed; the target is the industrial-equilibri- } \\
\text { um exchange rate. }\end{array}$ \\
\hline $\begin{array}{l}\text { 10. The Central Bank and the government } \\
\text { each have a sole mandate: to determine, } \\
\text { respectively, the short-term interest rate and } \\
\text { fiscal policy. }\end{array}$ & $\begin{array}{l}\text { 10. The Central Bank and the government } \\
\text { may, in addition, buy reserves, impose capital } \\
\text { controls etc. }\end{array}$ \\
\hline $\begin{array}{l}\text { 11. An income policy is not required or } \\
\text { desirable. }\end{array}$ & $\begin{array}{l}\text { 11. Minimum wage and minimum-income } \\
\text { policies should contribute to ensuring that } \\
\text { wages grow as fast as productivity. }\end{array}$ \\
\hline
\end{tabular}

${ }^{9}$ On flexsecurity see Robert Boyer (2006). 
For the new developmentalism medium-term domestic financing is essential for development, and it is the state's role to ensure it through its own banks and private banks. Foreign financing, however, is undesirable, since it appreciates the domestic currency and eventually promotes an increase in consumption rather than an increase in investment. The new developmentalism believes that it is not only possible but also necessary for a country to grow with its own savings, as did all the countries that have already developed and are currently rich. This does not mean that the new developmentalism is against foreign direct investment; its opposition is to current account deficits. It is perfectly possible for a country to benefit from the technology introduced by direct investment without using that investment to finance current-account deficits. This is what China does, for instance.

The basic assumption underlying the macroeconomic policies compared in Table 3 is the need for macroeconomic stability. But whereas conventional orthodoxy ultimately restricts the concept of stability to the control of public expenditure and inflation, the new developmentalism applies it more broadly to include the stability of asset prices or the control of financial bubbles, balance-of-payments equilibrium, and reasonably full employment.

Unlike with conventional orthodoxy, with the new developmentalism fiscal adjustment aims not merely at a primary surplus but at positive public savings, and implies a decrease not only in current expenditure but also in interest rates. The Central Bank, together with the Ministry of Finance, has three mandates: to control inflation, to ensure full employment, and to keep the exchange rate at a level compatible with the stability of the balance of payments and with the necessary incentive to export-oriented investments. The Central Bank's instruments go beyond the interest rate. The interest rate is an instrument to fight inflation, but it can be much lower in middle-income countries than assumed by conventional orthodoxy.

Given the existence of the tendency to the overvaluation of the exchange rate, and, for that reason, because it is chronically overvalued, the exchange rate in developing countries should be floating but managed. A variable tax on exports of commodities originating the Dutch disease, the formal rejection of current account deficits, capital controls, and buying of international reserves are the main instruments that policymaker dispose to manage the exchange rate.

Advocates of conventional orthodoxy accuse developmentalist economists of populism. If we understand economic populism to mean that the public sector or the whole country is spending irresponsibly more than it gets, when this applies to the public sector or the state organization and express itself under the form of budget deficits, we have fiscal populism, when it applies to the nation-state under the form of current-account deficits, we have exchange rate populism. By neutralizing the Dutch disease, new developmentalism argues in favor of a current-account surplus (derived from the shift of the exchange rate toward the industrial equilibrium) and a public surplus (derived from not using the revenues from the tax that neutralizes the disease to finance current expenditure). It counts with the substantially higher rates of growth to more than compensate the restraint implied in this twin surplus. Differently, conventional orthodoxy is satisfied with a primary surplus, 
and advocates that the country incur in current account deficits that keeps it hobbled by excessive foreign debt and by financial fragility vis-à-vis the rest of the world.

\section{REFERENCES}

BOYER, Robert (2006) La flexicurité danoise? Quels enseignements pour la France? Paris: Editions Rue d'Ulm.

BRESSER-PEREIRA, Luiz Carlos (2008) “Dutch disease and its neutralization: a Ricardian approach”, Brazilian Journal of Political Economy 28 (1) January: 47-71.

BRESSER-PEREIRA, Luiz Carlos (2010) Globalization and Competition, Cambridge: Cambridge University Press.

BRESSER-PEREIRA, Luiz Carlos e Paulo GALA (2007) “Why foreign savings fail to cause growth", Brazilian Journal of Political Economy 27 (1): 3-19. In Portuguese, in the printed edition; in English, in the journal's websites: www.rep.org.br.

CORDEN, W. M. (1984) "Booming sector and Dutch disease economics: survey and consolidation", Oxford Economic Papers 36 (3): 359-380.

CORDEN, W. M. and J. P. NEARY (1982) "Booming sector and de-industrialization in a small open economy”, Economic Journal 92 (368): 825-848.

FURTADO, Celso (1957 [2008]) “O desenvolvimento recente da Venezuela”, in Celso Furtado, Ensaios sobre a Venezuela. Rio de Janeiro: Contraponto e Centro Celso Furtado, pp. 35-118.

KEYNES, John Maynard (1980) Activities 1940-46: Shaping the Post World: Employment and Commodities, in Collected Writings, vol. XIII. London: Macmillan. Quoted by Luiz Fernando de Paula (2008).

PALMA, Gabriel (2005) “Four sources of 'de-industrialization' and a new concept of Dutch Disease”, in José Antonio Ocampo (ed.), Beyond Reforms: Structural Dynamics and Macroeconomic Vulnerability. Stanford: Stanford University Press and World Bank.

PAULA, Luiz Fernando de (2008) "Política econômica para crescimento e estabilidade macroeconômica: uma abordagem keynesiana com uma referência para o Brasil”, in João Sicsú e Carlos Vidotto (eds.), Economia do Desenvolvimento. Rio de Janeiro: Elsevier-Campus.

ROWTHORN, Robert (1994) "Korea at the crossroads", Working Paper no. 11. ESRC Centre for Business Research, University of Cambridge.

SKIDELSKY, Robert (2009) Keynes: The Return of the Master. New York: Public Affairs. 